\title{
Mediastinal lipoblastoma: a rare entity discovered on physical exam
}

\author{
Shinban Liu, ${ }^{1}$ Reena Bakshi, ${ }^{2}$ George Ferzli ${ }^{1}$
}

${ }^{1}$ General Surgery, NYU Langone Medical Center, Brooklyn, New York, USA

${ }^{2}$ Department of Surgery, Maimonides Medical Center, Brooklyn, New York, USA

\section{Correspondence to}

Dr Shinban Liu,

shinban.liu@nyumc.org

Accepted 28 July 2018
D) Check for updates

(c) BMJ Publishing Group Limited 2018. No commercial re-use. See rights and permissions. Published by BMJ.

To cite: Liu S, Bakshi R, Ferzli G. BMJ Case Rep Published Online First: [please include Day Month Year]. doi:10.1136/bcr-2018 226393

\section{DESCRIPTION}

A 3-year-old male with no significant medical or surgical history presents to his paediatrician for annual examination. On auscultation, he was noted to have diminished left-sided breath sounds and heart sounds displaced to the right. The patient had no complaints of pain, difficulty swallowing, shortness of breath or dyspnoea on exertion. An initial chest X-ray was performed which demonstrated complete opacification of the left hemithorax with mediastinal shift towards the right. This was followed by a radiation dose reduced CT of the chest with intravenous contrast, which demonstrated a $7.8 \times 7.4 \times 13.3 \mathrm{~cm}$ fat density mass filling the majority of the left lung and extending to the pleura and mediastinum (figure 1A). The patient was optimised for the operating room and underwent a left lateral thoracotomy. Intraoperatively, the mass was identified and noted to have fusion to the pericardium and pleura in its superior margin with all other borders freely mobile. After careful dissection, the mass was removed in its entirety and grossly appeared to be mixed fatty and stromal connective tissue (figure 1B). The patient had an uncomplicated hospital course with postoperative chest X-ray demonstrating no significant haemothorax or pneumothorax (figure 2A) and was discharged home. Surgical pathology would ultimately return as mature lipoblastoma (figure $2 \mathrm{~B}$ ).

Lipoblastoma are exceedingly rare paediatric neoplasms that are generally well-encapsulated, fast growing and benign. While they most commonly appear in the trunk and extremities, they can present anywhere in the body. They are believed to have a $27 \%$ local recurrence rate with curative surgical excision as the primary mainstay of treatment. ${ }^{1}$ They have not been found to metastasise and only become symptomatic with mass effect on adjacent structures. Few cases of mediastinal lipoblastoma
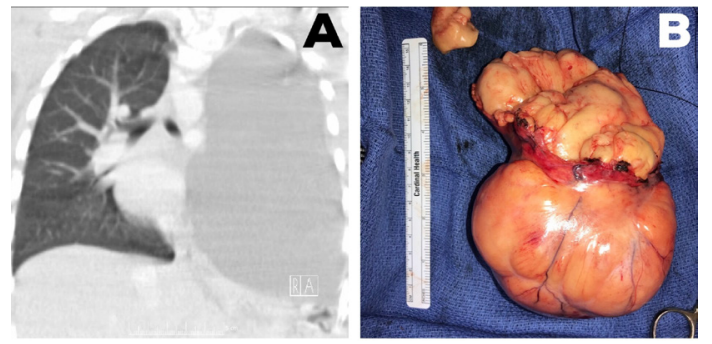

Figure 1 (A) Radiation dose reduced CT imaging with fat density filling the left hemithorax with mediastinal shift; (B) gross anatomic specimen with mixed fatty and stromal connective tissue.
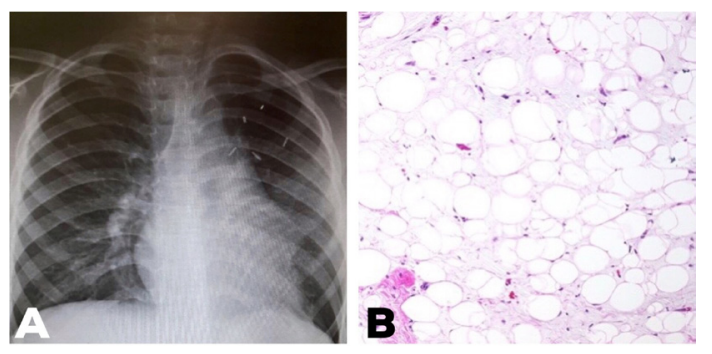

Figure 2 (A) Postoperative chest X-ray demonstrating no significant pneumothorax or haemothorax and partial re-expansion of left lung; (B) histopathology consistent with mature lipoblastoma.

are described in medical literature, and they represent a unique challenge due to the proximity of delicate and vital structures and require meticulous dissection for radical excision. After surgical resection, patients should have regular follow-up as local recurrence rates may range from $12 \%$ to $25 \%$ despite complete excision. ${ }^{2}$ This case represents a rare clinical entity where the neoplasm was discovered by astute physical examination rather than patient symptoms. The patient will continue to be followed annually for evaluation of recurrence with repeated CT if he develops new symptoms or abnormal physical exam findings.

\section{Learning points}

- Lipoblastoma are benign, well-encapsulated neoplasms that typically present before the age of 3.

- The recommended treatment is complete surgical excision.

- Good preoperative planning is required to determine resectable margins.

Contributors All authors contributed equally to the management of this patient, clinical write-up and drafting of this manuscript.

Funding The authors have not declared a specific grant for this research from any funding agency in the public, commercial or not-for-profit sectors.

Competing interests None declared.

Patient consent Parental/guardian consent obtained.

Provenance and peer review Not commissioned; externally peer reviewed.

\section{REFERENCES}

1 Pham NS, Poirier B, Fuller SC, et al. Pediatric lipoblastoma in the head and neck: a systematic review of 48 reported cases. Int J Pediatr Otorhinolaryngol 2010;74:723-8.

2 Mentzel T, Calonje E, Fletcher CD. Lipoblastoma and lipoblastomatosis: a clinicopathological study of 14 cases. Histopathology 1993;23:527-33. 
Copyright 2018 BMJ Publishing Group. All rights reserved. For permission to reuse any of this content visit http://group.bmj.com/group/rights-licensing/permissions.

BMJ Case Report Fellows may re-use this article for personal use and teaching without any further permission.

Become a Fellow of BMJ Case Reports today and you can:

- Submit as many cases as you like

- Enjoy fast sympathetic peer review and rapid publication of accepted articles

Access all the published articles

- Re-use any of the published material for personal use and teaching without further permission

For information on Institutional Fellowships contact consortiasales@bmjgroup.com

Visit casereports.bmj.com for more articles like this and to become a Fellow 